\title{
Ultrasound spectroscopy as an alternative method to measure the physical-chemical constituents of buffalo milk
}

\author{
Waldjânio de Oliveira Melo ${ }^{1^{*}}$ Bruno Moura Monteiro $^{2}$ Luciara Celi da Silva Chaves ${ }^{3}$ \\ Eduardo Riodades Daher Santos ${ }^{4}$ Damazio Campos de Souza ${ }^{5}$ Bianca Souza de Amorim ${ }^{3}$ \\ Sebastião Pereira de Faria Junior ${ }^{6}$ José Dantas Ribeiro Filho $^{7}$ Cristian Faturi $^{3}$ \\ Rinaldo Batista Viana ${ }^{3}$
}

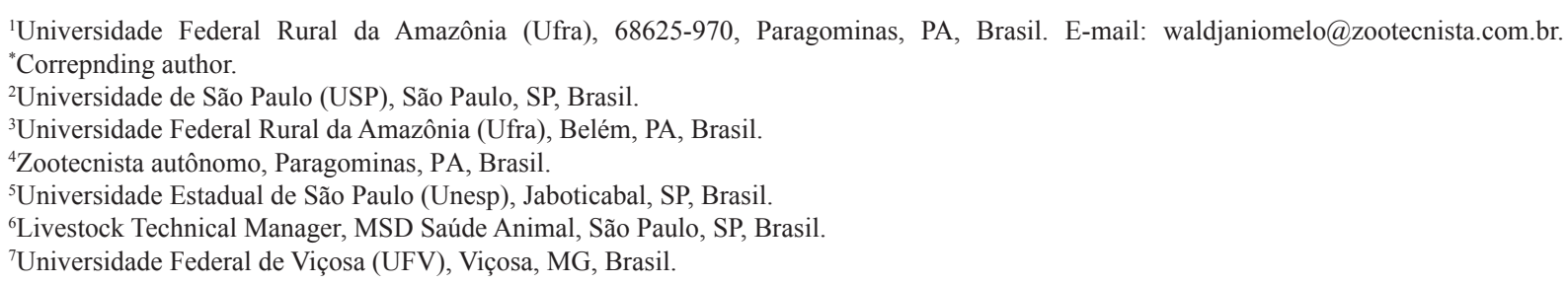

ABSTRACT: This study aimed to use ultrasound spectroscopy for the determination of the physical-chemical characteristics of buffalo milk and compare it to theinfrared method. Levels of fat, protein, lactose and non-fat solids (NFS) were determined in milk samples of 22 buffaloes $(n=383)$ with initial milk production of $6.97 \pm 1.55$ litres. The respective average results for the fat, protein, lactose and NFS of the individual samples were $6.31 \%, 3.81 \%, 4.99 \%$ and $9.75 \%$ for the infrared method-PO ANA 009 and $7.16 \%, 2.5 \%, 6.28 \%$ and $9.41 \%$ using ultrasound spectroscopy. There were significant differences $(P<0.0001)$ in the levels of all of the components analysed between the two methods studied. Results obtained in the analyses using the ultrasonic milk analyser (Ekomilk Total ${ }^{\mathbb{B}}$ ) were different from those obtained by the infrared method-PO ANA 009 (ESALQ), but they showed a high positive correlation for fat $(r=0.84108, P<0.0001)$, moderate correlation for NFS( $r=$ $0.71284 P=0.0022)$, low correlation for lactose $(r=0.32197 ; P<0.0001)$ and the absence of correlation for protein $(r=-0.00284, P<0.0001)$. Therefore, ultrasound spectroscopy can be used forthe determination of fat. For the other constituents of buffalo milk, in order to use the ultrasonic analyser, it is suggested that further studies should be conducted for technical and methodological adjustments.

Key words: buffaloes, milk composition, fat, protein, infrared.

Espectroscopia de ultrassom como método alternativo para a determinação das características físico-químicas do leite de búfalas

RESUMO: Objetivou-se com este trabalho o uso da espectroscopia de ultrassom para a determinação das características físico-químicas do leite de búfalas frente ao métodoinfravermelho. As características de gordura, proteína, lactose e estrato seco desengordurado (ESD) foram

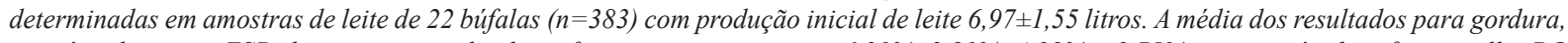
proteina, lactose e ESD das amostras individuais foram, respectivamente, 6,31\%, 3,81\%, 4,99\% e 9,75\% para o método infravermelho-PO ANA 009 e 7,16\%, 2,5\%, 6,28\% e 9,41\%, usando-se espectroscopia de ultrassom. Houve diferença significativa (P<0,0001) entre os teores de todos os componentes analisados entre os dois métodos estudados. Os resultados obtidos nas análises com o método utilizando analisador ultrassônico de leite (Ekomilk Total ${ }^{\mathbb{}}$ ) foram diferentes daqueles feitos por infravermelho-PO ANA 009 (ESALQ), porém, apresentaram correlação positiva alta para gordura $(r=0,84108 ; P<0,0001)$, moderada para ESD $(r=0,71284 ; P=0,0022)$, baixa para lactose $(r=$ 0,32197; $P<0,0001)$ e ausente para proteína $(r=-0,00284 ; P<0,0001)$, podendo, portanto, ser utilizado para determinação de gordura. Para os demais constituintes do leite de búfalas sugere-se, que para a utilização do analisador ultrassônico, mais estudos para ajustes técnicos e metodológicos sejam feitos.

Palavras-chave: Bubalinos, composição do leite, gordura, proteina, infravermelho.

\section{INTRODUCTION}

The quality of milk can be determined by physical, chemical,microbiologicaland sensoryanalysesas well as hygiene tests. For this purpose, there are several official methods available, as determined by the current legislation, which are performed by the Brazilian Network of Laboratories for Milk Quality Control. Such methods include the infrared method-PO ANA 009 (BRASIL, 2006). Although, easy to carry out, official tests often require specific forms of preservation and expensive analytical reagents and can be timeconsuming depending on the distance between the farm and the accredited laboratory (GONÇALVES, 2014). 
A method that is increasingly applied in the industry for the analysis and modification of food is ultrasound spectroscopy, which is based on the principle of sound absorption changing the frequency of the sample particles. It presents advantages over the traditional methods as it precludes the need forthe preparation of the samples, uses minimum volumes of the samples in a non-destructive way, precluding the need to use specific chemical reagents or glassware and produces results in only a few minutes (PONSANO et al., 2007). It has already been demonstrated in cattle that it is possible to determine the constituents of milk, both at the farm and at the dairy fair, allowing problems to be solved that require an immediate decision or to define the industrial destination of raw material (PINTO et al., 2008).

Despite the advantages ofultrasound spectroscopyas an alternative technique for the evaluation of milk constituents, it is worth mentioning that both the calibration tests of the devices and the comparative studies between the techniques were performed only using bovine milk (PONSANO et al., 2007; PINTO et al., 2008), and there is no study in the literature comparing them in buffalo milk, which has a different composition from that of bovine milk (AMARAL et al., 2005). Thus, the need for studies to develop automated analytical procedures, which are quick, accurate and of lower cost, for the analysis of the constituents of buffalo milk is evident.

Therefore, theaim of the present study was tocompare the physical-chemical parameters of buffalo milk obtained by the infrared method-PO ANA 009as well as an ultrasonic milk analyser (EKOMILK total $^{\circledR}$, Eon Trading LLC, Bulgaria) and to identify which buffalo milk constituents may be determined using ultrasound spectroscopy.

\section{MATERIALS AND METHODS}

The experiment was conducted at a farm located in the municipality of Mojú ( $1^{\circ} 54^{\prime} 14.33^{\prime} \mathrm{S}$; $\left.48^{\circ} 46^{\prime} 07.53^{\prime \prime} \mathrm{W}\right)$, a mesoregion of the northeastern region of Parástate, Brazil. The climate of the region is characterized as Ami (hot and humid) according to the Köppen-Geiger climate classification, with an annual average temperature between 25 and $27^{\circ} \mathrm{C}$ and annual precipitation between 2,000 and $3,000 \mathrm{~mm} / \mathrm{m}^{2}$ with an irregular distribution. The relative air humidity is approximately of $85 \%$ (SILVA et al., 2001).

Individual milk samples were collected for 11 weeks $(n=383)$ from 22 adult buffaloes of similar genetic groups, mostly Murrah (Bubalus bubalis) or crossbred (with genetic predominance of theMurrah breed) lactating buffalos. All buffaloes were multiparous with a mean of $66 \pm 1.74$ days in lactation (DIL) anda production of $6.97 \pm 1.55$ litres of milk per day at the beginning of the study. Animals were kept under a rotational stocking system on Urochloa (Brachiaria) humidicola, Urochloa (Brachiaria) brizantha and Panicum maximum cv. Mombasa pastures, receiving water and mineral salt ad libitum.In addition to pastures, the lactating buffaloes received $1.0 \mathrm{~kg}$ of feed/day, composed of $30.61 \%$ murumuru cake (Astrocaryum murumuru), $61.29 \%$ maize meal (Zea mays), 3.1\% mineral mix and $5 \%$ urea. Thebromatological composition of the diet was $93.02 \%$ dry matter (DM), $8.41 \%$ mineral matter (\%), $18.17 \%$ crude protein (CP), 3.15\% etherextract (EE), $23.9 \%$ neutral detergent fibre (NDF) and $10.96 \%$ acid detergent fibre (FDA), with results obtained using the methodology described by SILVA \& QUEIROZ (2002).

The buffaloes were milked manually twice a day with an average interval of 12 hours between milking. The control of milk production was carried out weekly, with complete emptying of the udder 12 hours beforeat the intervals of $63-70 ; 70-77 ; 77-84$; 84-91; 91-98; 98-105; 105-112; 112-119; 119-126; 133-140; and 147-154 days in lactation. On the same day of the milk control, always at the end of each milking and after the homogenization of the total milk, the samples were collected to determine the physical-chemical composition of the milk for the comparison between the analysis methods.

Of the total milked milk, aliquots of the sample wereplaced in sterile (labelled) $50 \mathrm{~mL}$ vials containing microtablets of bronopol-based preservatives and stored in thermal boxes containing ice packs. Samples were then sent to the Luís de Queiroz College of Agriculture (ESALQ/USP), in PiracicabaSão Paulo State, accredited by the Brazilian Network for Milk Quality Control of the Ministry of Livestock and Food Supply (RBQL/MAPA), for the determination of fat, protein, lactose and non-fat solids (NFS) by the infrared method-PO ANA 009 according to the collection, preservation and evaluation recommendations of the laboratory.

Other aliquots of the milk sample wereplaced in sterile (labelled) preservative-free $75 \mathrm{~mL}$ bottles and stored in thermal boxes containing ice packs. Within a maximum of 24 hours, these samples were analysed in the food analysis laboratory of the Federal Rural University of the Amazon-Ufra (BelémParástate) for the determination of fat, protein, lactose and NFS using ultrasound spectroscopy(EKOMILK 
total $^{\circledR}$, Eon Trading LLC, Bulgaria) following the manufacturer's recommendations.

The descriptive statistics of the data, represented by the means, standard error of the means (SEMs) and the minimum as well as maximum values for each variable were obtained through the MEANSprocedure of SAS version 9.3 (SAS/STAT, SAS Institute Inc., Cary, NC). Comparison between the means of the groups was performed by analysis of variance (ANOVA) using the LSMeans (Least Square Means)/PDIFF ILINK LINES command from SAS. Toassess the correlation between the variables analysed by infrared method-PO ANA 009 and ultrasound spectroscopy (EKOMILK total ${ }^{\circledR}$, Eon Trading LLC, Bulgaria), the CORR RANK procedure from SAS was used.

Toestimate the milk constituents, such as fat, protein, lactose and NFS, the infrared methodOP ANA 009 (ESALQ) and the ultrasonic analyser (EKOMILK total ${ }^{\circledR}$,Eon Trading LLC, Bulgaria) were used. The data were tested by means of regression analysis withtheGLMprocedure from SAS, using the least squares method for simple non-polynomial regression. For the calculation of the regressions and Pearson's correlations, the coefficients of determination $\left(\mathrm{R}^{2}\right)$ of $\geq 0.70, \geq 0.50$ and $<0.50$ as well as correlation coefficients of $(r)$ $\geq 0.80, \geq 0.70$ and $<0.70$ were considered high, moderate and low, respectively. The Pvalue was considered significant when $\leq 0.05$.

\section{RESULTS AND DISCUSSION}

The mean, standard error and minimum and maximum values obtained for the buffalo milk constituents by the different methods are presented in table 1. Additionally, using the infrared method-PO ANA 009 of the Milk Clinic-ESALQ/USP, NERES et al. (2013) reportedmean values of $6.9 \pm 1.5 \%$ fat, $5.1 \pm 0.3 \%$ protein, $5.0 \pm 0.4 \%$ lactose and $10.9 \pm$ $0.8 \%$ NFS, while LIMA et al. (2014) observed mean valuesof $5.44 \%$ fat, $4.24 \%$ protein and $4.77 \%$ lactose in buffalo milk. Thus, the lower level of milk protein obtained in the present study wasthe only variable that did not present similar behaviourto the studies by NERES et al. (2013) and LIMA et al. (2014).

In relation to the results obtained by ultrasound spectroscopy (EKOMILK), in the present study, the mean values were different from those reported by PESSOA et al. (2011) in buffaloes, in which mean valuesof $5.4 \pm 2.1 \%$ fat, $5.2 \pm 0.3 \%$ protein, $5.1 \pm$ $0.6 \%$ lactose and $11.1 \pm 1.0 \%$ NFS were found.

Differences in milk composition are caused by the effects of environmental factors, such as the season and nutrition, as well as animal-related factors, such as the breed, age and lactation stage (AMARAL et al., 2005). Milk components (fat, protein, lactose and NFS) may vary according to the nutrition, season andanimal-related effects, such as the age, breed and stage of lactation (DAMÉ et al., 2011), which explains the differences observed between some of the buffalo milk constituents in several studies.

Table 1- Mean values, standard errors of the mean, minimum and maximum values of the production variables and physical-chemical analysis of buffalo milk obtained by ultrasound spectroscopy (EKOMILK total ${ }^{\circledR}$, Eon Trading LLC, Bulgaria) and the infrared method-PO ANA 009 (ESALQ/USP).

\begin{tabular}{|c|c|c|c|c|}
\hline Variables & Mean & SEM & Minimum & Maximum \\
\hline Number of milk samples & \multicolumn{4}{|c|}{ 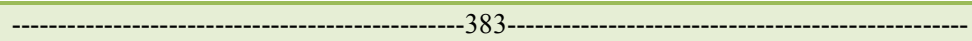 } \\
\hline \multirow[t]{2}{*}{ Milk production per day, $\mathrm{kg}$} & 3.39 & 0.07 & 0.10 & 10.10 \\
\hline & \multicolumn{4}{|c|}{ 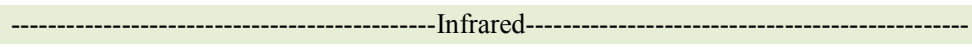 } \\
\hline Fat $\%$ & 6.31 & 0.07 & 2.31 & 14.75 \\
\hline Protein $\%$ & 3.81 & 0.02 & 2.58 & 4.81 \\
\hline Lactose $\%$ & 4.99 & 0.01 & 3.26 & 5.57 \\
\hline \multirow[t]{2}{*}{ NFS \% } & 9.75 & 0.02 & 7.53 & 10.83 \\
\hline & \multicolumn{4}{|c|}{ 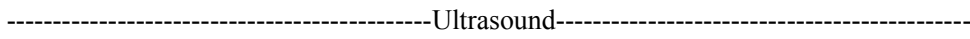 } \\
\hline Fat $\%$ & 7.16 & 0.07 & 3.10 & 12.90 \\
\hline Protein $\%$ & 2.51 & 0.05 & 1.52 & 12.48 \\
\hline Lactose $\%$ & 6.28 & 0.02 & 2.60 & 7.10 \\
\hline NFS $\%$ & 9.41 & 0.02 & 7.66 & 10.80 \\
\hline
\end{tabular}

NFS: non-fat solids 
There were significant differences between the levels of fat, protein, lactose and NFS ( $P<0.0001)$ for the ultrasound spectroscopy analysis compared to the infrared method used by reference laboratories (RBQL/MAPA). In a similar research; however, with milk samples from nine Holstein cows, PINTO et al. (2008) reported significant differences between the levels of fat ( $\mathrm{P}$ $=0.0001)$ and NFS $(\mathrm{P}=0.0001)$ when comparing the ultrasonic and infrared methods but without any differences for the protein content $(\mathrm{P}=0.1782)$. According to the authors, the differences between the fat and NFS levels of the milk found between the two methods used are possibly due to differences in the calibration of the two devices.

The correlation results between the fat, protein, lactose and NFS of buffalo milk obtained by ultrasound spectroscopy comparedwith theinfraredmethodare presented in table 2. Figure 1 shows the dispersion, regression equation and respective coefficient of determination for the fat, protein, lactose and NFS percentages obtained by the infrared method-PO ANA 009 or ultrasonic milk analyser (EKOMILK total $^{\circledR}$, Eon Trading LLC, Bulgaria). In a similar study, PINTO et al. (2008) reported a positive and significant correlation for the levels of fat $(r=0.98, \mathrm{P}=$ $0.0001)$ and NFS $(r=0.85, \mathrm{P}=0.0041)$ obtained with the two methods studied. However, unlike the results of the present study, these authors reported a positive correlation for the protein level $(r=0.83, \mathrm{P}=0.0051)$.

A high correlation coefficient was reported only for the fat concentration, and a moderate correlation was found for the NFS portion between the two evaluated methods, unlike some studies
(PINTO et al., 2007; SILVEIRA et al., 2004) that compared the ultrasonicanalyser with other methods of milk analysis. The results obtained in the analyses using the ultrasonic milk analyser (Ekomilk Total ${ }^{\circledR}$ ) were different from those obtained by infrared method-PO ANA 009 (ESALQ) but showed a high positive correlation for fat $(r=0.84108, \mathrm{P}<0,0001)$, a moderate correlation for $\operatorname{NFS}(r=0.71284 \mathrm{P}=$ $0.0022)$, a low correlation for lactose $(r=0.32197$; $\mathrm{P}$ $<0.0001)$ and the absence of correlation for $\operatorname{protein}(r$ $=-0.00284, \mathrm{P}<0.0001)$; and therefore, ultrasound spectroscopy can be used for fat determination.

The differences between results of the determination of protein, lactose and NFS levels of milkfor the infrared method-PO ANA 009 (ESALQ) and ultrasonic milk analyser (EKOMILK total ${ }^{\circledR}$, Eon Trading LLC, Bulgaria) is possibly due to differences in calibration between the two devices, use of preservatives and time between the collection and samples analysis .

\section{CONCLUSION}

Despite the advantages of ultrasound spectroscopyas an alternative technique for the evaluation of buffalo milk constituents, it is a safe method only for the determination of fat levels. However, for the other constituents, more research is required, as there are still few studies evaluating the influence of the factors that affect buffalo milk analysis on both methods, and technical as well as methodological adjustments such as conservation methods, whether or not to use preservatives, temperature and the time of sample collection and processing are also needed.

Table 2 - Correlation coefficients and significance levelsbetween levels of fat, protein, lactose and NFS obtained by ultrasound spectroscopy(EKOMILK total ${ }^{\mathbb{B}}$, Eon Trading LLC, Bulgaria) and the infrared method-POANA 009 (ESALQ/USP).

\begin{tabular}{|c|c|c|c|c|c|}
\hline \multirow{2}{*}{ Variables } & & \multirow[b]{2}{*}{ Fat** } & \multirow[b]{2}{*}{ Protein** } & \multirow[b]{2}{*}{ Lactose** } & \multirow[b]{2}{*}{ NFS** } \\
\hline & & & & & \\
\hline \multirow{2}{*}{ Fat* } & $R$ & 0.84108 & -0.0152 & -0.22730 & -0.17666 \\
\hline & $\mathrm{P}$ & $<0.0001$ & 0.0744 & $<0.0001$ & $<0.0001$ \\
\hline \multirow{2}{*}{ Protein* } & $R$ & 0.29428 & -0.00284 & 0.26035 & 0.38036 \\
\hline & $\mathrm{P}$ & $<0.0001$ & 0.9559 & $<0.0001$ & $<0.0001$ \\
\hline \multirow{2}{*}{ Lactose* } & $r$ & -0.15890 & 0.12280 & 0.32197 & 0.42075 \\
\hline & $\mathrm{P}$ & $<0.0001$ & 0.0165 & $<0.0001$ & $<0.0001$ \\
\hline \multirow{2}{*}{ NFS* } & $r$ & 0.15649 & 0.05909 & 0.42696 & 0.71284 \\
\hline & $\mathrm{P}$ & 0.0022 & 0.2499 & $<0.0001$ & $<0.0001$ \\
\hline
\end{tabular}

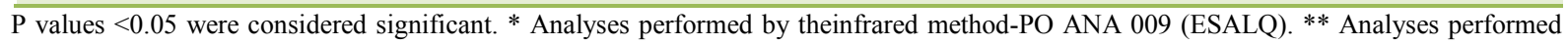
using the ultrasonic milkanalyser (EKOMILK total ${ }^{\mathbb{B}}$, EonTrading LLC, Bulgaria). NFS: non-fat solids. 
A

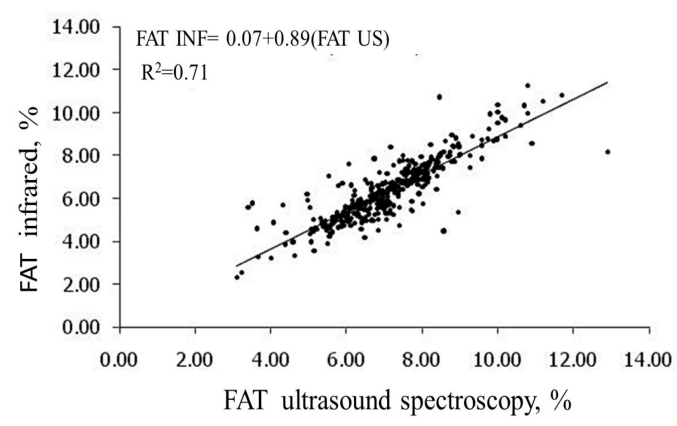

C

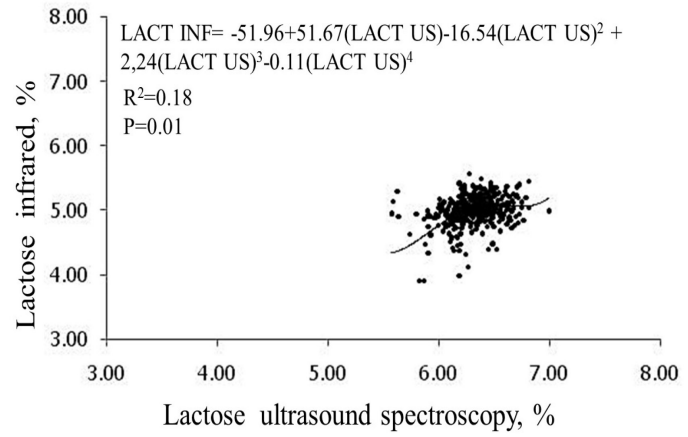

B

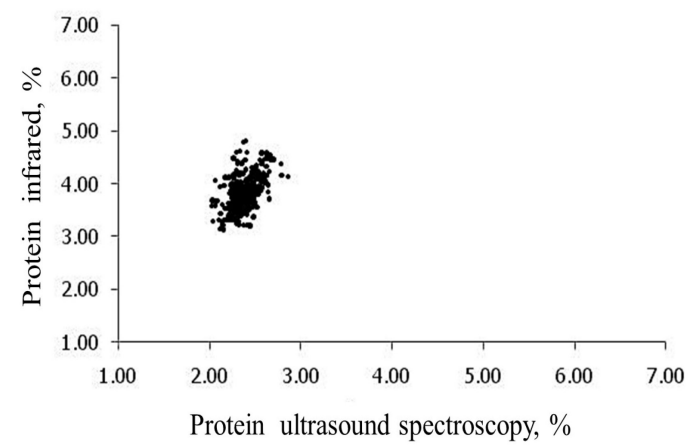

D

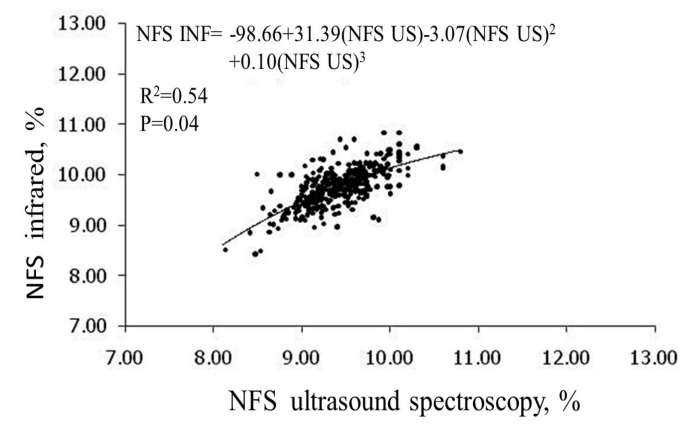

Figure 1 - Dispersion diagram, simple non-polynomial regression equation, coefficient of determination $\left(\mathrm{R}^{2}\right)$ and significance level (P) between levels of fat (A), protein (B), lactose (C) and non-fat solids (D) obtained by ultrasound spectroscopy (EKOMILK total ${ }^{\circledR}$, Eon Trading LLC, Bulgaria) and the infrared method-PO ANA 009 (ESALQ/USP).

\section{ETHICS AND BIOSAFETY COMMITTEE}

The experiment was approved by the Ethics Committee on Animal Use of Universidade Federal Rural da Amazônia (UFRA), Protocol 021/2016 (CEUA)-23084.006670/2016-28 (UFRA), which confirmed that all the requirements of Federal Law 11.794/08 (Arouca Law) were complied with, as were the Ethical Principles of Animal Experimentation of Colégio Brasileiro de Experimentação Animal (COBEA).

\section{REFERENCES}

AMARAL, F. R. et al. Buffaloes milk quality: components. Revista Brasileira de Reprodução Animal.V.29, n.2, p.106-110, 2005. Available from: < http://www.cbra.org.br /pages/publicacoes/rbra/ download/RE022.pdf $>$ Accessed: 17 jun. 2017.

BRASIL. Instrução Normativa $n^{\circ} 68$ de 12 de dezembro de 2006. Oficializa os Métodos Analíticos Oficiais Físico-Químicos, para Controle de Leite e Produtos Lácteos, em conformidade com o anexo desta Instrução Normativa, determinando que sejam utilizados nos Laboratórios Nacionais Agropecuários. Diário Oficial da União, Brasília, 2006. p. 8.

DAMÉ, M.C.F. et al. Produção e Qualidade de Leite de Bubalinos no Rio Grande do Sul: dados preliminares.Pelotas: Empresa Brasileira de Pesquisa Agropecuária Embrapa Clima Temperado. 2011. 14p. (Documento 296).

GONÇALVES, A.C.S. Avaliação dos resultados das contagens de células somáticas obtidas pelo equipamento Ekomilk Scan ${ }^{\circledR}$ e suas correlações com outros métodos de análise. 2014.35f. Dissertation (Mestrado em Medicina Veterinária) - Universidade Estadual Paulista, Jabotical-SP.

LIMA, T.C.C.; RANGEL, A.H.N.; MACÊDO, C.S. et al. Composition and quality of milk and whey buffalo in Rio Grande do Norte state. Acta Veterinaria Brasilica. v.8, n.1, p.25-30, 2014. Available from: $<$ https://periodicos.ufersa.edu.br/revistas/index. php/ acta/article/ view/3321/5392> . Accessed: mar. 03, 2017. doi: 10.21708/avb.2014.8.1.3321.

Ciência Rural, v.48, n.2, 2018. 
NERES, L.S. et al. Quality of creamy requeijão cheese of buffalo milk supplemented with byproducts agribusiness, Belem, Para State, Brazil. Revista do Instituto Laticínios Cândido Tostes. v. 68, n. 391, p. 24-31, 2013. Available from: <https://rilct.emnuvens. com.br/rilct/article/view/18/19>. Accessed: mar. 03, 2017.

PESSOA, J.S. et al. Physicochemical characteristics of milk during different stages of lactation of water buffalo(Bubalus bubalis) heifers raised on pasture. In REUNIÃO ANUAL DA SOCIEDADE BRASILEIRA DE ZOOTECNIA, 48., 2011, Belém. Anais... Belém: [s.n] 2011.p.1-3.

PINTO, A.T. et al. Correlation between infra-red and ultrasound methods to evaluate milk composition in milk contestat EXPOINTER 2007. Acta Scientiae Veterinariae. v.36, n.3, p. 273-276, 2008. Available from: <http://www.lume.ufrgs.br/ bitstream/handle/10183/20719/000681368.pdf?sequence $=1>$ Accessed: mar. 04, 2017.

PONSANO, E.G.H. et al. Correlation between traditional methods and ultrasonic spectroscopy for measurement of milk physical- chemicalcharacteristics. Arquivo Brasileiro de Medicina Veterinária e Zootecnia, v.59, n.4, p.1052-1057, 2007. Available from: <http://www.scielo.br/pdf/abmvz/v59n4/35.pdf>. Accessed: 02 de fev.2017. doi: 10.1590/S0102-09352007000400035.

SILVA, D.J.; QUEIROZ, A.C.Q. Análise de Alimentos: Métodos químicos e biológicos. 3 ed. Viçosa, MG, editora UFV, 235p. 2002.

SILVA, S. M. A. S. et al. Impacto da exploração madeireira em floresta de terra firme no município de Moju, estado do Pará. In: SILVA, J. N. M; CARVALHO, J. O. P.; YARED, J. A. G. (Eds.). A silvicultura na Amazônia Oriental: contribuições do projeto Embrapa/DFID. Belém: Embrapa Amazônia Oriental - DFID, 2001. p. $227-251$.

SILVEIRA, T.M.L.et al.. Comparison between standard methods and electronic analyses for measurement of the bovine milk composition. Arquivo Brasileiro de Medicina Veterinária e Zootecnia, v.56, n.6, p.782-787, 2004. Available from: <https:// doaj.org/article/656253b2769846e1abbcca7fe03fb5af $>$. Accessed: mar. 05, 2017. doi: 10.1590/S0102-09352004000600013. 